\title{
Gárgulas: representações do feio e do grotesco no contexto português. Séculos XIII a XVI
}

Tese de Doutoramento em Belas Artes, especialidade Ciências da Arte, apresentada à Faculdade de Belas Artes da Universidade de Lisboa, 2011. Orientação da Prof. ${ }^{a}$ Doutora Margarida Calado.

Catarina Fernandes Barreira

\section{CpenEdition}

\section{Journals}

\section{Edição electrónica}

URL: http://journals.openedition.org/medievalista/849

DOI: 10.4000/medievalista.849

ISSN: 1646-740X

\section{Editora}

Instituto de Estudos Medievais - FCSH-UNL

Edição impressa

Data de publição: 1 Janeiro 2012

\section{Refêrencia eletrónica}

Catarina Fernandes Barreira, « Gárgulas: representações do feio e do grotesco no contexto português Séculos XIII a XVI », Medievalista [Online], 11 | 2012, posto online no dia 26 fevereiro 2014, consultado no dia 19 abril 2019. URL : http://journals.openedition.org/medievalista/849; DOI : 10.4000/

medievalista.849 
Título: Apresentação de Tese

Gárgulas: representações do feio e do grotesco no contexto português. Séculos XIII a XVI.

Tese de Doutoramento em Belas Artes, especialidade Ciências da Arte, apresentada

à Faculdade de Belas Artes da Universidade de Lisboa, 2011. Orientação da Prof. ${ }^{a}$

Doutora Margarida Calado.

Autor(es): Catarina Fernandes Barreira

Enquadramento Institucional: Instituto de Estudos Medievais FCSH - UNL

Contacto: fernandesbarreira@gmail.com

Fonte: Medievalista [Em linha]. №11, (Janeiro - Junho 2012). Dir. José Mattoso. Lisboa:

IEM.

Disponível em: http://www2.fcsh.unl.pt/iem/medievalista/

ISSN: 1646-740X 


\section{Apresentação de Tese}

Gárgulas: representações do feio e do grotesco no contexto português.

Séculos XIII a XVI.

Tese de Doutoramento em Belas Artes, especialidade Ciências da Arte, apresentada à Faculdade de Belas Artes da Universidade de Lisboa, 2011. Orientação da Prof. ${ }^{a}$ Doutora Margarida Calado.

\section{Catarina Fernandes Barreira}

A investigação apresentada resultou de um estudo interdisciplinar entre a Estética e a História da Arte e constituiu-se como um trabalho pioneiro no que concerne ao objecto de estudo e às suas abordagens, mas especialmente pelos contributos que possa vir a trazer para o desenvolvimento dos estudos medievais, em particular no campo das mentalidades e da sua relação com a produção de imagens.

Um dos nossos objectivos foi o de tentar perceber se a realização e presença das gárgulas figurativas nos edifícios religiosos do território nacional, do século XIII ao século XVI foi ou não uma presença fundamentada e legitimada do ponto de vista teórico pelo feio e pelo grotesco. Ou seja, perguntamos se as gárgulas foram esculpidas e validadas a partir de um corpus estético que se constituiu como território do feio e do grotesco. No intuito de cumprirmos com o nosso propósito tentámos perceber como é que os estetas e os teólogos medievais entendiam aquilo a que hoje chamamos obra de arte, uma vez que uma gárgula figurativa, embora tenha de ser interpretada enquanto parte da escultura monumental de um edifício, tinha uma vida própria cuja identidade foi profundamente marcada pelos modos como os homens da Idade Média entendiam as imagens e as funções que lhes estavam reservadas.

Em seguida a nossa intenção foi problematizar as ideias relativas ao feio: o que era entendido como o feio para a estética medieval (iniciámos a nossa reflexão pela Patrística e estendemo-la para além da Escolástica), mas não sem antes questionarmos a 
reflexão estética da Antiguidade Clássica, importante porque a Idade Média foi dela herdeira. Por fim, averiguámos se as gárgulas nacionais reflectiram de algum modo estes aspectos, embora de forma indirecta: uma porção dos textos que estiveram na base do corpus teórico relativo ao feio circularam em Portugal, em contexto monástico e conventual, dos finais do século XIII ao século XVI, com particular ênfase para o período compreendido entre o século XV e as primeiras décadas da centúria seguinte, período que coincidiu com o apogeu da colocação de gárgulas nos edifícios religiosos. Estes aspectos constituem um dado importante sobre a circulação e permanência destes textos entre nós, muitos deles a circularem já impressos. Pesem embora estes fenómenos, não parece ter havido, entre nós e por parte dos nossos teólogos, discussão estética sobre o feio: o termo aparece amiúde nos textos, numa relação directa com as noções de adequação e conveniência, de cariz moralizante, mas desligado das imagens e da criação artística em geral.

Associado à mudança de paradigma estético ocorrida nas primeiras décadas de Quinhentos temos o fenómeno do grotesco, significativo pela sua relação com o feio e porque a presença das gárgulas nos edifícios religiosos se prolongou muito para além da mundividência medieval, cujos últimos episódios se estenderam até depois de Trento (as últimas gárgulas deste estudo foram lavradas no reinado de D. Sebastião, que terminou em 1578). Podemos mesmo dizer que ao feio do hibridismo medieval sucedeu o grotesco do hibridismo classicista, teorizado por eruditos portugueses como Leão Hebreu, João de Barros e Francisco de Holanda.

Postas estas considerações, imprescindíveis para o enquadramento estético da questão, foi na segunda parte do trabalho que nos dedicámos ao estudo e análise das gárgulas, da sua relação com a história dos edifícios e da sua proximidade com a época e com as mentalidades.

No que concerne à revisão bibliográfica, em contexto internacional, nomeadamente anglo-saxónico, as gárgulas têm vindo a ser encaradas como tendo funções apotropaicas e de amuleto, em simultâneo com a sua associação ao mal e ao demoníaco. Em contexto nacional e no que diz respeito às primeiras gerações de historiadores da arte, nomeadamente Virgílio Correia e João Barreira, as gárgulas foram entendidas como meramente decorativas, manifestações populares e pagãs, marginalia e ainda como 
fugas ao controlo eclesiástico. Esta última ideia justificava um número muito reduzido de gárgulas a ilustrar temas de cariz transgressor, o que não se veio a verificar: a razão para a sua justificação teria de ser outra. Mais recentemente, as gárgulas passaram a ser encaradas como significativas para a compreensão da mundividência medieval, graças aos trabalhos desenvolvidos por Saúl Gomes, José Custódio V. da Silva e Luís Urbano Afonso, mas carecendo ainda de um estudo abrangente e comparativo. É de referir o trabalho iniciado por Ana Patrícia Rodrigues Alho que deve trazer contributos importantes ao estudo das funções hidráulicas das gárgulas nos edifícios.

O campo de estudo desta investigação foi constituído por cerca de 74 casos de edifícios religiosos do território nacional com gárgulas, do século XIII ao XVI. No que concerne à sua localização geográfica, os edifícios distribuem-se de Norte a Sul do país (por motivos que se prenderam com a falta de tempo, as ilhas dos Açores e Madeira ficaram por realizar, abrindo perspectivas para novas investigações), com destaque para o Litoral Centro, onde encontramos um número significativo de edifícios com gárgulas. Em relação à quantidade de gárgulas por edifício, temos um número bastante variável: desde uma gárgula, da igreja de Sta. Clara do Porto até quase às duas centenas dos núcleos de Sta. Maria da Vitória, Sta. Maria de Belém e Convento de Cristo, em Tomar. Estes dados foram articulados com a vida dos edifícios: intervenções posteriores, ampliações, melhoramentos e campanhas de restauro onde, por vezes, foram retiradas ou colocadas gárgulas não previstas inicialmente.

No que diz respeito ao tipo de edifício religioso, temos 8 sés com gárgulas, 38 igrejas matrizes, ermidas e capelas e 28 espaços monásticos e conventuais (em que duas dezenas pertencem a ordens mendicantes). Fomos indagar também junto da arquitectura militar da época, em particular as torres de menagem: embora o âmbito desta investigação se restringisse às gárgulas dos edifícios religiosos, a arquitectura militar também as exibe e foram essenciais para a problematização e articulação temática. No que concerne à sua localização, as gárgulas podem pontuar todo o edifício religioso, ou estarem confinadas em áreas como as fachadas, galilés, torres, a zona da cabeceira e claustros. Em relação a estes espaços, o seu usufruto quase exclusivo pela comunidade religiosa afecta ao edifício foi um aspecto que não foi descurado na elaboração dos programas iconográficos, bem pelo contrário: a especificidade do público-alvo das 
gárgulas constituiu um importante factor na construção dos seus programas iconográficos.

Um dos capítulos mais significativos desta investigação foi o levantamento de fontes de inspiração para a realização de gárgulas: esta tentativa de levantamento de pontos de partida para as gárgulas, objectos estéticos profundamente comprometidos com a sua época e com as mentalidades, englobou um leque alargado e diversificado de fontes que dependeu do triângulo mecenas/imaginário/público-alvo. Um aspecto a destacar: só excepcionalmente verificámos uma relação directa entre fontes de inspiração e gárgulas: uma boa porção do trabalho assentou num tecido social e religioso comum à produção de textos e à produção de gárgulas, tecido esse que se exprimiu numa dimensão colectiva ao ser presentificado nas gárgulas e que a partir das mesmas interveio socialmente. Estas fontes incluíram a literatura moralizante, obras de apoio à prática da confissão dos séculos XIV, XV e XVI, Autos de Visitação, relatos de viagens, provérbios e ditos populares, formas de saber de carácter hermético como a Alquimia, bem como a outras manifestações artísticas, numa variedade complexa que ainda assim não esgotou o assunto e que constitui potencial para posteriores investigações.

Postas estas considerações iniciais, partimos para o levantamento dos edifícios com gárgulas. A organização escolhida partiu da evolução cronológica, dividida por reinados: não se tratou de uma proposta de periodização, mas um tipo de organização que serviu única e exclusivamente este trabalho, com estas características relativas ao objecto de estudo. Isto também se deveu ao facto de termos alguns edifícios com mais do que uma campanha de colocação de gárgulas, em que o caso mais paradigmático foi a Sta. Maria da Vitória, com seis campanhas distintas que se estenderam desde a primeira metade do séc. XV a cerca de 1533. Deste modo obtivemos algumas vantagens face a uma organização monográfica, pois facilmente detectámos as dinâmicas características de uma época, que temas foram maioritariamente explorados e que tipos de programa caracterizaram determinado período. Cada edifício mereceu uma pequena abordagem histórica introdutória onde articulámos as questões da autoria, os mestres, a equipa de imaginários: para um edifício como Sta. Maria de Belém tivemos a sorte de estarem publicados os cadernos de obras, onde pudemos conferir o nome dos imaginários autores de algumas gárgulas, bem como o respectivo pagamento e, para o 
estaleiro em análise, o facto de não ser um ofício em exclusivo para os imaginários, que se dedicavam também a lavrar todo o tipo de elementos escultóricos monumentais.

Para cada edifício procedemos à localização das gárgulas na planta e/ou em fotografias do mesmo, para depois realizarmos a sua análise, problematização e também articulação com outros núcleos, sempre que se justificou pela importância e complexidade de fontes e programas. Daqui resultou uma certa heterogeneidade na dimensão dos capítulos, consequência directa não do número de gárgulas, mas da sua complexidade iconológica e dos programas, bem como de outros aspectos relevantes.

De forma concisa, podemos traçar um panorama breve da evolução das gárgulas nos nossos edifícios religiosos:

- Do século XIII aos finais do século XIV temos um número modesto: 7 casos de edifícios, onde verificamos uma relação formal com a escultura monumental românica, embora sem ligação geográfica, pois a maioria destes núcleos encontra-se no Centro e no Sul. Para este período, a experiência mais significativa foi o estaleiro da Sé de Évora, cujas gárgulas já anunciam a vocação moralizante que as caracterizou mais para a frente.

- Na Dinastia de Avis, de D. João I a D. João II temos mais 7 casos, aliados a 3 campanhas de colocação de gárgulas em Sta. Maria da Vitória. Neste ciclo, a evolução temática e formal resultou em parte do rescaldo da Sé eborense e da dinâmica inerente

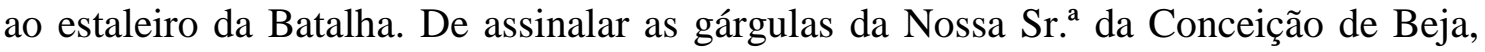
um núcleo muito significativo em termos plásticos e temáticos, embora com um número modesto de gárgulas.

- No reinado de D. Manuel temos os grandes estaleiros manuelinos: a continuação da empreitada de Sta. Maria da Vitória, na Batalha, Sta. Maria de Belém e o coro alto do Convento de Cristo, em Tomar, para além de outros edifícios, não menos importantes,

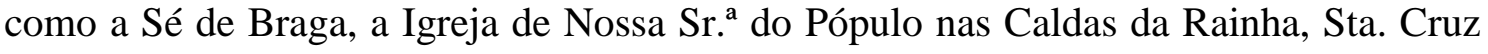
de Coimbra e Sta. Maria de Alcobaça, cujos programas se complexificaram em articulação com um clima propício ao início da reforma religiosa das ordens e do clero 
em geral. O grande destaque deste período centrou-se na importância que a figura humana ganhou na presentificação de pecados, enquanto exemplum.

- O apogeu da colocação de gárgulas nas edificações religiosas não foi um fenómeno confinado ao reinado de D. Manuel, mas que incluiu o reinado seguinte, devido a vários factores: o prolongamento das campanhas de obras de edifícios começados no reinado do Venturoso, mas somente concluídos no reinado de D. João III; as persistências estéticas dos mestres e dos imaginários, educados em estaleiros manuelinos e, por fim, a própria resistência à mudança por parte dos mecenas. Neste período constatámos um número significativo de núcleos com programas eruditos, embora em simultâneo com núcleos marcados por arcaísmos formais e temáticos que, em termos plásticos, evocam ainda a escultura românica.

- Entre o reinado de D. João III e o reinado de D. Sebastião (1578), embora em decréscimo, manteve-se a colocação de gárgulas nos edifícios: temos casos de gárgulas em edifícios de charneira como por exemplo, as edificações levantadas em Tomar por João de Castilho, as Sés de Leiria e de Portalegre e a Igreja Matriz de Torre de Moncorvo. Verificamos assim uma predominância da função pedagógica das gárgulas em detrimento da coerência estética, em paralelo com uma actualização do ponto de vista formal das gárgulas, agora próximas das tendências clássicas e mesmo maneiristas, no caso das gárgulas do Claustro da Manga em Coimbra. No que concerne aos aspectos temáticos, neste período mantiveram-se os temas anteriores, justificados agora pelo clima de reforma das ordens.

Após o levantamento e estudo das gárgulas dos edifícios destacámos dois fenómenos que foram absolutamente relevantes para este estudo das gárgulas: por um lado, os contributos do "nomadismo artístico", um conceito do historiador João Barreira (que já tivemos oportunidade de estudar noutras provas académicas) e, por outro, os aspectos "portuguesistas" (um conceito do Prof. Jorge Henriques Pais da Silva). O primeiro fenómeno atesta a importância da circulação de artistas e de obras, quer do exterior para Portugal, quer entre os estaleiros nacionais: acreditamos que este fenómeno foi responsável pela introdução de gárgulas figurativas no nosso país e por uma porção significativa das renovações temáticas e formais ocorridas. Em relação ao 
"portuguesismo" acreditamos que esteve na base de uma certa persistência relativamente a aspectos formais e temáticos nas gárgulas, pelo conservadorismo estético, bem evidente na colocação epigonal e tardia de gárgulas em edificações de charneira e em edifícios clássicos e por um tipo de identidade programática que caracterizou o panorama nacional.

Como notas finais nesta investigação queremos destacar o empenho e participação da igreja no geral e junto das várias ordens religiosas em particular, no desenho dos programas numa estreita colaboração com os imaginários. Só deste modo se justificam as diversas temáticas, em particular as aparentemente transgressoras como as representações de freiras e frades nus, a exibirem ou a taparem os órgãos genitais, gestos repetidos também por alguns animais. Ou a presentificar os pecados que mais preocupavam o clero, como a luxúria e a gula, o que estabeleceu interessantes paralelos com os manuais de apoio à prática da confissão e com a literatura moralizante da época. A complexidade de alguns dos programas iconográficos resultou do cariz erudito no que concerne às fontes usadas, nunca secundarizando a articulação entre mecenas/imaginários/público. As gárgulas também serviram para integrar e legitimar socialmente muitas das novidades resultantes do contacto dos portugueses com outros povos, culturas e geografias: destacam-se as representações de negras e negros, índios brasileiros, macacos, um rinoceronte, em paralelo com outra fauna resultante do maravilhoso do imaginário tardo-medieval.

As gárgulas revelaram um importante comprometimento com a sua época e com as mentalidades, em particular através de uma vincada vocação pedagógica/catequética. A sua validade pedagógica sobrepôs-se mesmo ao rigorismo e despojamento característico das ordens, em particular junto dos menoritas e dos cistercienses: num universo de 28 edifícios monásticos e conventuais, aos franciscanos pertencem 15 casos de edificações com gárgulas, o que enfatiza a sua exploração didáctica por parte desta ordem mendicante. No caso de Cister, a sua colocação ocorreu já no âmbito da crise que afectou a ordem, nas primeiras décadas de Quinhentos, numa estreita proximidade dos temas com o espírito reformista.

Para concluir esta apresentação de tese, cabe ainda assinalar as suas fragilidades: ficou por fazer o estudo das gárgulas das ilhas dos arquipélagos dos Açores e da Madeira e a 
comparação com o contexto internacional, em particular junto do contexto espanhol e francês. Estes dois aspectos constituem-se como potencial para investigações posteriores, abrindo as portas para novas conclusões.

\section{COMO CITAR ESTE ARTIGO}

\section{Referência electrónica:}

BARREIRA, Catarina - Gárgulas: representações do feio e do grotesco no contexto português. Séculos XIII a XVI. Tese de Doutoramento em Belas Artes, especialidade Ciências da Arte, apresentada à Faculdade de Belas Artes da Universidade de Lisboa em 2011. Medievalista [Em linha]. No 11, (Janeiro - Junho 2012). [Consultado dd.mm.aaaa]. Disponível em http://www2.fcsh.unl.pt/iem/medievalista/MEDIEVALISTA11 lbarreira1112.html. ISSN 1646-740X.

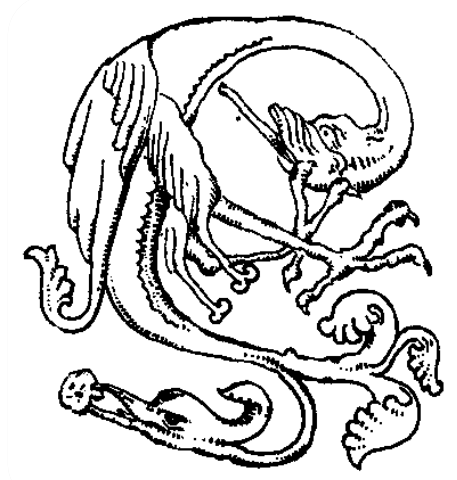

